\title{
THE APPLICABILITY OF ADMINISTRATIVE LAW PRINCIPLES TO ISSUES OF PRIVATISATION IN INDIA
}

\author{
Lisa P. Lukose *
}

\begin{abstract}
Privatisation is an exclusive subject of governmental policy in several countries. The reasons for privatisations may mainly be political and economical; nevertheless, it raises many legal questions. Apart from the constitutionality and legality of the decision on privatisation there are public law issues in administrative law that usually crop up with privatisation decisions. The principle aim of this article is to examine the applicability of administrative law principles in privatisation. In the initial part, the article examines the phenomenon, various approaches towards privatisation, its rationale and limitations. Subsequently, the article analyses different types of privatisation. It also portrays various interfaces between privatisation and administrative law with special reference to India. In the last part, the article is summed up with an appropriate conclusion and suggestions.
\end{abstract}

Key words: privatisation, administrative law principles, public law, regulation of privatisation, effect on human rights

Associate Professor, University School of Law and Legal Studies, GGS Indraprastha University, Delhi, India, email: lisrobin@gmail.com. 


\title{
MENGGUNAPAKAI PRINSIP UNDANG-UNDANG ADMINISTRATIF DALAM ISU PENSWASTAAN DI INDIA
}

\begin{abstract}
ABSTRAK
Penswastaan merupakan satu perkara eksklusif dalam dasar kerajaan di beberapa negara. Sebab-sebab penswastaan mungkin menjurus kepada aspek politik dan ekonomi, namun ianya membangkitkan banyak persoalan perundangan. Selain daripada samada keputusan untuk penswastaan itu menepati perlembagaan dan perundangan, terdapat juga isu-isu undang-undang awam dalam undang-undang pentadbiran yang berbangkit dengan adanya keputusan penswastaan. Tujuan utama makalah ini ialah mengkaji penggunaan prinsip-prinsip undang-undang pentadbiran dalam penswastaan. Pada bahagian awal, makalah mengkaji fenomena, pendekatan-pendekatan terhadap penswastaan, rasional dan batasan-batasannya. Kemudian, makalah menganalisa jenis-jenis penswastaan. Ia juga menunjukkan hubungkait antara penswastaann dan undang-undang pentadbiran dengan rujukan khas kepada India. Dalam bahagian akhir, makalah diringkaskan dengan rumusan yang sesuai dan cadangan-cadangan.
\end{abstract}

Kata kunci: penswastaan, undang-undang pentadbiran, undangundang awam, kawal atur penswastaan, kesan terhadap hak kemanusiaan

\section{INTRODUCTION}

Administrative law, which is basically a part of public law, primarily deals with administrative or governmental actions. Public law is regarded, for the purpose of this paper, as that area of constitutional, administrative, criminal and international law that focuses on the organisation of the government, the relations between the state and its citizens and the responsibilities of government officials. Although 'privatisation' is a matter of public policy, initiating it raises many challenges and several implications in public law. ${ }^{1}$ The issue of

Privatisation is a topic for discussion in other branches of law also such as (i) labour law - with respect to the rights of employees when their company is privatised; (ii) criminal law - expanding the application of offenses which have 
privatisation requires not only doctrinal adjustments but re-evaluation of the area of public law, focusing on 'public law of privatisation.'

In the contemporary world, where human society is undergoing rapid transition in terms of its demands and expectations, the governments are trying to address these demands by changing, reforming and even reinventing policies. The primary task before any government is economic development, which is a multi-dimensional task covering a wide range of political, economic, social, technical and cultural activities. $^{2}$ Privatisation has become a global phenomenon to achieve swift economic growth. This article seeks to capture public law issues with special focus on administrative law issues in privatisation from the Indian and Malaysian experience. At appropriate places, this article discusses cases, practices and experiences from other countries as well.

\section{PRIVATISATION}

Privatisation means different things to different people, ${ }^{3}$ as there are indeed various meanings of privatisation. Generally the term, 'privatisation' is being used as a panacea for many economic problems especially relating to public enterprises. ${ }^{4}$ Privatisation is a phenomenon which is opposite of the phenomenon of nationalisation. Upendra Baxi defines privatisation as the 'constitutional other' of nationalisation. ${ }^{5}$ It is both a matter of public policy and a matter of law. Privatisation aims at reducing governmental intervention in social and economic life of the people.

The first expression of privatisation happens by transferring government assets such as land, holdings in government companies

been erstwhile limited to employees of public agencies, (iii) constitutional law with respect to the employees of the private contractors of the government, (iv) private law - increasing role of private entities in the public sphere resulting increasing demand for social responsibility of businesses, etc.

2 S Yadav and N Yadav, "Governance in India and Public Private Partnership: A Paradigm Shift," Indian Journal of Public Administration 3 (2008): 638-53.

3 U Baxi, "Privatisation is a Coat of Many Colours," Mainstream, January 13, 1999, 33.

4 A P. Saxana, 'Privatisation: Cure or Curse,' Economic and Political Weekly 21 (1993): 1036.

5 U Baxi, "Constitutional Perspectives on Privatization: A Footnote to Dalip Swamy," Mainstream, July 6, 1991, 33. 
etc. to private hands. Privatisation may also occur by inviting private activity in new sectors through governmental passivity, for example, contracting with private companies for the supply of services or public goods. Another type of privatisation is a system of development of industries when economic development is introduced in a nascent economy. In some cases, privatisation may take the form of complete withdrawal of government from operating in certain fields. In certain situations, privatisation may denote mere transfer of supply of social services to private entities while leaving the management and responsibility in the hands of the government.

The capitalist method of industrialisation in macro-perspective is also referred to as industrialisation through the private sector. In such a situation the role of government is gradually reduced to virtual nothingness and the private sector becomes increasingly powerful. The state becomes a representative of the capitalist. Privatisation of this genre is gradually spreading its tentacles over macro-economic set up. ${ }^{6}$

\section{Various Approaches}

There are many approaches to privatisation. The 'traditional approach' treats privatisation solely as a matter of 'policy' thereby minimising legal intervention. This approach neither considers privatisation as a central challenge to public law nor recognises legal and constitutional challenges of privatisation. Rather it regards that the privatisation decisions never raise any legal questions. Focusing on the constitutional neutrality of many countries towards privatisation, this approach holds that selling of government companies/assets (one form of privatisation) has no constitutional meaning though this may raise economic and ideological issues. The traditional approach argues that constitutional law should not interfere with the decision to privatise although it should address the consequences of privatisation. ${ }^{7}$ However, the new patterns of the

6 BN Ghosh, "Privatisation, Market Power and Allocative Inefficiency: Reflections on the Malaysian Example," Mainstream, April 4, 1998, 15. Also see, C Samson, "The Three Faces of Privatisation," Sociology 1 (1994): 79-97.

7 See generally, D Barak-Erez, "Constitutional Limitations on Privatization in Israel" Israeli Reports to the XV International Congress of Comparative Law (1999): 317. Also see, Eytan Sheshinski and Luis F. López-Calva, "Privatization and Its Benefits: Theory and Evidence," Cesifo Economic Studies 3 (2003): 429-459. 
privatisation render the traditional approach outdated. When privatisation changes its nature by allowing private entrepreneurs to enter into core government functions and to social services, the constitutional neutrality approach requires reconsideration.

The 'permissive approach' towards privatisation centres on the ultra vires principle meaning that privatisation decisions should be based on legislative authorisation. Legislatures often support privatisation enabling statutes. In many countries no express authorisation for privatisation is ever expected as there is an implied authority for the state to embark on privatisation initiatives which even the courts have recognised. ${ }^{8}$ This approach firmly holds that administrative authorities can discharge their functions even by contracting with private entities. The approach that the authority for privatisation may either be express or implied would raise issues in the process of regularising privatisation.

\section{Rationale for Privatisation}

Many of the countries experimented with privatisation against the background of the economic crisis in 1970. In western countries privatisation of some units has been the policy of governments. ${ }^{9}$ The British government implemented privatisation until 1991, when the privatisation cycle was assumed to have been nearly complete. It began in Canada in 1979. It was subsequently followed in Japan, France, West Germany etc. The French programme lasted for a short period with loss of majority in the parliament. In 1980s, the IMF's and the World Bank's pressure on India to reduce the financial and administrative burden by privatising some PSU's (public sector undertaking) made the Indian government to realise the need for privatisation and to lean towards privatisation and liberalisation. Even in countries which has the policy of nationalisation, it is still perceived as an exception and such initiatives are considered

8 See Israeli court's observations in Adam Teva V'din-Israel Union for Environmental Defense v.Municipality of Raanana 59 (2) PD 210 (2004).

9 British Telecom, British Gas and British Airways were privatised during the regime of Margaret Thatcher. 
provisional steps, with the long term intent to return to privatisation when the time is ripe. ${ }^{10}$

The reasons for privatisation are political, social and economical, rather than legal. The main reasons are operational inefficiencies in the public enterprises; ${ }^{11}$ the public enterprises' continuous losses and deficit $^{12}$ (for example, like many countries India reports loses despite being overprotected ${ }^{13}$ ) governmental failure, governmental passivity, governmental withdrawal and introduction of new services which the people have never enjoyed earlier such as internet services, cellular phone services etc.

Privatisation is based on the premise that there must be equalisation of the human conditions for the good life and equality of opportunity for work and enjoyment. Privatisation presupposes the acceptance of the principle of non-discrimination. The reasons and justifications for privatisation in many countries including India and Malaysia are the following:

10 D Barak-Erez, 'Three Questions of Privatization,' accessed May 20, 2015, http://www.law.yale.edu/documents/pdf/CompAdminLaw/Daphne_Barak-Erez_ CompAdLaw_paper.pdf.

11 The root cause of privatisation is the inefficiency of public enterprise which is usually measured with the help of financial profitability; see, P Trivedi, "What is India's Privatisation Policy" Economic and Political Weekly 22 (1993): 71. For the opposite view, see, D M Bhouraskar, 'Privatisation Policy,' Economic and Political Weekly 34 (1993): 1747 wherein Bhouraskar argues that an approach towards privatisation based merely on an analysis on different types of losses is inadequate and misleading and distracts from an objective search for a rationale for privatisation. According to him, profits vary as much for different types of public enterprises and this may be due to easier access to credit, concessional terms of finance, government guarantees on enterprise borrowing, nonenforcement of standards, subsidised inputs, guaranteed internal demand, lower levels of executive compensation and other privileges enjoyed by public enterprises.

12 The public enterprises' deficits have added to the country's large stock of domestic and external public debt which in turn results in massive annual liabilities on account of interest payments. See, AP Gupta, "Political Economy of Privatisation in India," Economic and Political Weekly 39 (1996): 2687.

13 Gupta, "Political Economy," 2687-94. The author writes that "these enterprises' operational inefficacies are so huge that they exceed the benefit resulting from the substantial protection that they enjoy and as a consequence, they incur losses. With protection level coming down, with competition increasing and with many qualified people leaving public enterprises because of substantially better opportunities available in the private sectors, the public enterprises' financial performance may worsen". 
i. Promotes the consumers' freedom of choice: The study conducted in Chile, Malaysia, Mexico and UK shows that through privatisation, consumers benefited from improved services, substantial increase in welfare, etc. ${ }^{14}$

ii. Commercial viability: Privatisation offers more satisfactory and quality services. ${ }^{15}$ However, in India, despite huge investment in public sector undertakings ('PSUs') the return of investment is negligible. ${ }^{16}$ Ever increasing loss or continuous fall in profitability is a common phenomenon in Indian PSUs. The responsibility and success of PSUs is now being evaluated on the same line as in the private sector enterprises and major emphasis is being given on their commercial viability. ${ }^{17}$

iii. More economic growth: Privatisation can improve the environment in which public enterprises operate and thereby strengthen the manager's incentive to be efficient, which in turn will contribute to making the Indian economy substantially more efficient. Economic and social benefits of privatisation are apparent in both developing and developed countries. The basis for privatisation in Malaysia was in keeping with current economic thinking. ${ }^{18}$ The Malaysian government has identified five different policy objectives for

In Chaoulli v. Attorney General of Quebec (2005) 1 SCR 791 the Supreme Court of Canada held that the prohibition on private health insurance in Quebec violated the basic rights of the petitioners, who were interested in such insurance against the background of an unsatisfactory level of public health care. The court also noted that the prohibition infringed the rights protected by section 7 of the Canadian Charter in Liberties and Freedoms which protects the security of the person.

16 PSUs in India are working in key areas of industries including coal, steel, minerals, metals, heavy equipments, power, service sectors such as tourism, foreign trade, shipping, transportation, consultancy, construction and small scale industry etc.

17 E Hussain, "Is Privatisation the only Answer?" Mainstream, September 14, 1991, 29.

18 Shankaran Nambiar, "Revisiting Privatisation in Malaysia: The Importance of Institutional Process," Asian Academy of Management Journal 2 (2009): 21-40. For economic and efficiency considerations of privatisation, refer, Maxim Boycko, Andrei Shleifer and Robert W. Vishny, "A Theory of Privatisation," The Economic Journal 435(1996): 309-19. 
its privatisation policy, of which contributing to the New Economic Policy is the most important.

iv. Removal of concentration of economic powers: By encouraging new class entrepreneurs, privatisation helps to satisfy the legitimate aspirations of weaker sections of society which did not have their share in the benefits of economic growth. By upholding the validity of the privatisation decision in the Indian telecom industry, the supreme court of India opined in Delhi Science Forum \& Others $v$ Union of India \& Another ${ }^{19}$ that "the new Telecom Policy is not only a commercial venture of the Central Government, but the object of the policy is also to improve the service so that the said service should reach the common man and should be within his reach." In Malaysia, privatisation covers cases where less than half of the assets or shares of state owned enterprises (SOEs) are sold to private shareholders. In fact, privatisation is usually understood to also include cases of partial divestiture where less than half of the assets or shares of SOEs are sold to private shareholders, with the government retaining control through majority ownership. ${ }^{20}$

v.Efficiency considerations: Privatisation is one of the major elements of the adjustment process with a view among others, to making enterprises and economies productive and competitive.$^{21}$ It is meant to improve the efficiency of state owned enterprises. ${ }^{22}$ Many economists use the efficiency argument as a major reason to justify privatisation. ${ }^{23}$

1996 (2) SCC 405.

Jomo K. S. and Tan Wooi Syn, "Privatization and Renationalization in Malaysia: A Survey", accessed August 10, 2015, http://unpan1.un.org/ intradoc/groups/public/documents/un/unpan021546.pdf

21 C S Venkata Ratnam, "Social and Labour Issues in Privatisation- An Overview," IJIR 2 (1992): 139.

22 SK Majumdar \& G Ahuja, “Privatisation: As Exegesis of Key Ideas," Economic and Political Weekly 27 (1997): 32.

23 Samuel Paul, "Privatisation and Deregulation," Economic and Political Weekly' 26 (1992): 1339. However, Paul wonders whether a mere test of efficiency as measured by profitability between the private and public sectors at a given point of time is the right perspective from which one should judge the case for privatisation in India, especially in view of the fact that the public sector is also 
Financial performance, though relevant, cannot be the determining factor in decisions relating to privatisation. Efficiency considerations ${ }^{24}$ - allocative and productive are more important and privatisation is justified when competition in the market place can improve the efficiency of a public enterprise. ${ }^{25}$ The disinvestment in government companies would serve the twin purpose of funding the development of infrastructure and helping the denationalised units perform competitively. ${ }^{26}$

vi.Enhances investment: Privatisation can create conditions suitable for substantial additional investment bringing labour market reforms.

vii. Foreign direct investment: It reduces public sector deficit and attracts considerable inflow of direct foreign investment. In Sri Lanka, a ten year privatisation drive from 1989-1998 itself generated Rs. 47.3 billion (US \$ 715 million) to the government. It attracted foreign investments of around US \$ 465 million, easing domestic liquidity conditions and strengthening the country's external assets. ${ }^{27}$

viii. Liberty: Indian experience shows that as a result of privatisation the working of banks and insurance companies etc. is more liberalised and widespread with the removal of many limitations in their functioning. For example, as per section 23 of the Reserve Bank of India Act, 1934 banks have

engaged in many activities for which economic profitability need not be the only test.

24 The studies conducted in past which compared public enterprises' performance before and after privatisation in many countries show considerable efficiency gains that have resulted from privatisation. See, Gupta, "Political Economy," 2687.

25 Bhouraskar, "Privatisation Policy," 1747.

26 See, Toh Kin Woon, "Privatization in Malaysia: Restructuring or Efficiency?" ASEAN Economic Bulletin 3 (1989): 242-58. Also see, for benefits of privatisation, Loizos Heracleous, "Privatisation: Global Trends and Implications of the Singapore Experience" International Journal of Public Sector Management 5 (1999): 432 - 44.

27 Rozana Salih, "Privatization in Sri Lanka," in Privatization in South Asia: Minimising Negative Social Effects through Restructuring, ed. G. Joshi (ILO, 2000). 
to take permission for opening new branches but after privatisation it has become a mere formality. Bank and insurance are the two key financial sectors that have undergone privatisation in early 1990s in India.

\section{Limitations on Privatisation}

Amongst the public law issues of privatisation, which are primarily administrative law issues, the first question is what are the limitations attached on the spheres of privatisation. Can all areas of governmental activity be privatised? Or, are there some core government sectors (such as defence, judiciary/court, prison administration etc. even though there is no universally agreed definition for 'core'/ 'essential' government functions) which cannot be privatised at all?

While looking at the conditions in India, wholesale privatisation is undesirable as the private sector in India does not have the resources to take over and manage large public enterprises. Moreover, as many public sectors in India are overstaffed, private sectors taking over PSUs would find it difficult to get rid of excessive labour. Retrenchment would be a hard decision for the government.

The next limitation centres around privatisation is its legitimacy. The doctrine of ultra vires holds that if there is no legislative authorisation for privatisation, the privatisation initiative would be invalid. Whether a country needs to enact a privatisation law or can do without one depends on several factors such as the political situation and legal traditions of the country, the scope of its privatisation program, and the nature of the enterprises to be privatised, etc. ${ }^{28}$ The presumption against delegation of government powers to private bodies requires that privatisation must be based on express legislation. This requirement is an effective mechanism to regulate the process of privatisation. In the legislative process, the legislature gets ample freedom to deliberate and debate upon the questions, among others whether privatisation is required in a particular field; if required then to what extent and what are the measures to be adopted to ensure governmental supervision in the sectors of privatisation.

28 Pierre Guislain, Privatization Challenge: A Strategic, Legal and Institutional Analysis of International Experience (Washington D C: World Bank, 1997), 3343. 
According to Baxi, when a trade or industry is nationalised by legislation, it necessarily follows that it can be privatised only by a specific enactment for that purpose. Hence, a privatisation Act must disclose grounds on which public or community interest is better served by denationalisation. This is the Indian constitutional position in view of the equality clause under article 14 forbidding arbitrary and irrational state action. Thus, a mere repeal of the nationalisation legislation may be questioned as barring article $14 .{ }^{29} \mathrm{He}$ adds: ${ }^{30}$

The Indian Constitution is a salutary discipline on state power...it may be perceived by Justices to permit acts of denationalisation which are manifestly in public interest. But it prohibits donoragencies induced, or economistically populist (for a cross-section of India's troubled higher bourgeoisie), acts of undisciplined or unbridled acts of denationalisation. Responsible acts of denationalisation will be those which do not gift away on a silver platter state resource for private profit at the cost of the workers and society. The text and context of the Indian Constitution forbids altogether elected oligarchies in India from emulating the mercantilist state formative practices of the Company Bahadur.

In Centre for Public Interest Litigation $v$ Union of India, the Supreme Court of India restrained the Central Government from proceeding with disinvestment, resulting in Hindustan Petroleum Corporate Limited (HPCL) and Bharat Petroleum Corporate Limited (BPCL) ceasing to be Government companies without appropriately amending the concerned statutes suitably. ${ }^{31}$

There can also be limitations on the right to transfer government assets in the core sectors to third parties especially to hostile or foreign entities. Such sectors may be vital for the economy or for the security of the state. It is a control mechanism by which the states'

Baxi, "Privatisation is a Coat," 32.

Baxi, "Privatisation is a Coat," 34.

(2012) 3 SCC 1. It was argued that the decision of the Government to sell majority of shares in HPCL and BPCL to private parties without parliamentary approval or sanction is contrary to and violative of the provisions of the ESSO (Acquisition of Undertaking in India) Act, 1974, the Burma Shell (Acquisition of Undertaking in India) Act, 1976 and Caltex (Acquisition of Shares of Caltex Oil Refining India Limited and all the Undertakings in India for Caltex India Limited) Act, 1977. Also see, Vibha Mathur, Disinvestment of Public Sector Enterprises in India, Policies and Challenges (Delhi: New Century Publications, 2004). 
interest can be protected by limiting the right to further transfer the assets (the erstwhile government asset which is originally transferred by the government to a private entity) by private bodies to third parties. In such situations, the state can exercise the right to veto future transactions in the public interest.

Another perspective of privatisation is that of human rights. In privatisation, the fruits of economic progress are not shared equally. It flows into the pockets of traders, businessmen and industrialists which are against the principle of social justice. ${ }^{32}$ In the Indian constitutional mandate, Indian economic activity has to satisfy the demands of distributive justice and public interest. The court in Chandra Bhavan Boarding $v$ The State of Mysore ${ }^{33}$ declared the constitutional philosophy in the following lines: "The mandate of the Constitution is to build a welfare society in which justice, social, economic and political, shall confirm all institutions of national life. The hopes and aspirations aroused by the constitution will be belied if the minimum needs of the lowest of our citizens are not met." However, in the process of privatisation casualty is often public interest. ${ }^{34}$ Privatisation has created some improper behaviour in human beings. In a fully free economy and market oriented economy, people may follow illegal and corrupt paths for achieving maximum benefits.

\section{TYPES}

Privatisation can be through ownership changes, organisational changes or operational changes - there can be privatisation of ownership, privatisation of management or privatisation of enterprise disciplines in substantive terms. ${ }^{35}$ The following are types of privatisation:

32 S Mishra, "Principles of Social, Legal and Natural Justice," Supreme Court Journal 3 (1990): 3.

33 AIR 1970 SC 2042.

34 L Viswanathan \& R V Anuradha, "Liberalism, Public Interest and Indian Constitution," Journal of Indian Law Institute 36 (1994): 378.

35 SR Mohnot, ed., Privatisation: Option and Challenges (New Delhi: CIER, 1991), 2 . 
I. By establishing a government-owned corporation with an aim to sell the government stocks in the future to private hands, for example, the privatisation model of British Petroleum;

II. By selling government owned companies to private entities;

III. By outsourcing - it represents gradual reduction of governmental activity and hiring private contractors to carry out government activity. Outsourcing technical activities to private contractors (construction, garbage collection, school bussing and computer services or collection services are examples);

IV. By inviting private funding for governmental construction;

V. By allowing the private entrepreneurs to construct infrastructure for the government;

VI. By allowing the private entity to handle both, execution of the construction work and investment with an agreement that the private entity can operate the infrastructure through special concessions for a specified period. This model of privatisation secures private funding for construction. While the private entity administers the project they usually charge the public a fee for use of the infrastructure and gain profit. D P Erez describes this model as 'build-operate-transfer' (BOT), wherein the private investor builds the infrastructure at his expense, operates it over an agreed period of time and subsequently transfers ownership to the state.

VII. By granting licenses in core government sectors: The state grants licenses/permit in core government sectors. This enables the government to slowly avoid the need to provide state services. The private service providers with the state's permit expands their private activity into the hitherto state sectors such as education - by opening private schools and universities which enable the government to avoid the need to establish new government schools and universities; telecommunication etc.

VIII. By passivity of the government: The governmental failure to provide satisfactory service to the public. The 
health care sector and education sector are apt examples wherein public believe that they get better quality service from private service providers.

IX. By introducing fees to provide certain services: The government may introduce fees and entrust private agencies the task of collection of fees. Fees introduced in public parks, museums, public roads (toll) etc. are examples.

X. By commercialisation of public places: The public spaces wherein the government operates exclusively may be permitted to be used by the private agencies. Allowing private agencies to advertise in public places, for example, in schools, metros, trains, hospitals, governmental television and radio channels, etc. This will give a private face to the public place by the advertisement, the wishes and the preferences of private agencies which can afford paying for such advertisement.

XI. By giving special subsidies to the private service providers and the consumers who opt for private services.

XII. By institutionalising cooperation between private, public and the third sectors (NGOs). For instance, such joint schemes for helping the poor, vocational training for the unemployed, schooling for poor etc.

\section{PRIVATISATION VIS-A-VIS ADMINISTRATIVE LAW}

Though privatisation is partially addressed by public law doctrines, public law does not offer a comprehensive analysis of privatisation. In the realm of administrative law, in India's experience, privatisation raises certain fundamental questions such as (i) what is the scope of privatisation - the boundaries of privatisation? (ii) what are the limitations on the types of actions / powers that can be privatised? (iii) what should be the administrative process of privatisation including the privatisation policy of the government? and (iv) what are the impacts of privatisation? (v) which legal regime should apply to privatised activities? 
In Balco Employee's Union v Union of India, (The Balco case) ${ }^{36}$ employees of Balco Company challenged the administrative policy administrative power of the government on the matter of disinvestment of its stake in a government company and the procedure to be followed while deciding the question of disinvestment. While deciding the case, the Supreme Court of India held that the decision to disinvest and the implementation thereof is purely an administrative decision relating to the economic policy of the state. The labour could not claim a right, either on the basis of natural justice or any other foundation, to be consulted or the right to receive prior notice or to be consulted at every stage of the process. Even a government servant, having the protection articles 14 and 16 or article 311 of the Constitution of India had no absolute right to remain in service and therefore the decision to change the control of the Balco Company from government to private hands was the sole prerogative of the government and could not be challenged by the employees. $^{37}$

This decision certainly enhanced the level of administrative discretion that the executive enjoyed in the selection of and following of a policy which has a vital impact on the economic position of the country. The government has the power to decide as to the adoption of a policy of disinvestment as the determination of policy has always been within the domain of the executive. The court held that the principles of natural justice did not apply even in case where the rights of the employees were affected as regards the change of their employer. The silent approval of the disinvestment process by the apex court signals that disinvestment and privatisation are in the national interests and for the progress of the economy as a whole.

The Balco case also reveals the limits on judicial review of administrative actions. The courts would not interfere unless the policy adopted by the government suffered from the illegality or mala fide. The decision also stretches the scope of administrative powers in making a policy decision. The limit of public interest litigation vis-àvis disinvestment is also evident in the decision. ${ }^{38}$

\footnotetext{
$36 \quad 90$ (2001) DLT 789.

37 However, Sterlite Industries (the buyer) had given an undertaking that no employee of BALCO would be removed and the government had taken sufficient steps towards the protection of the employees.

38 J Tarun, 'A Critical Analysis of the Balco Case,' accessed January 20, 2015, http://ssrn.com/abstract=1087593.
} 
Further, privatisation is a political question. Considering that privatisation decisions are expressions of policy, it would be better not to shift such decisions from the political sphere to the constitutional sphere. However, with regard to recent developments, the approach that privatisation decisions are 'solely a matter of policy' requires reconsideration. The choice of activities for privatisation is again a matter of policy and not of law. However, both institution-based analysis and rights-based analysis show that there are certain activities that cannot be privatised such as criminal justice administration and defence because they are an integral part of the state.

To legitimise privatisation, there needs to be a policy. Lack of a comprehensive policy on privatisation defuses the scope for realising the potential gains of privatisation. A privatisation policy will also facilitate the process of reforms. At the stage of initiation of privatisation policies, the main legal issue is that of developing norms that will apply to private bodies which are involved in operating government-like functions. However, in India there is a lack of comprehensive policy on privatisation. Privatisation initiatives may be questioned on grounds of safeguards against infringements of fundamental rights by private actors vested with the responsibility formerly performed by public officials. In privatisation, the decision making process must be fair, thus ensuring equal opportunities to the potential bidders or contractors. There needs to be mandatory bidding rules and mandatory competition amongst the contractors to rule out bias and corruption. At the same time legal measures must be adopted to make certain that the state ensures the best prize from the highest bidder for maximising the economic benefit of privatisation. As discussed above, the concept of privatisation, to a large extent revolves around social and economic factors rather than legal.

The next question is whether privatised activities should be subject to the 'state action doctrine' or whether the said doctrine is limited to the 'traditional functions' of the state? In M C Mehta v Union of India (the Mehta case) ${ }^{39}$ the Supreme Court of India considered the issue whether a private entity discharging important public functions can be a State? The specific issue in the Mehta case was whether victims of a gas leakage from a private chemical and fertiliser plant could sue for compensation under article 32 of the 
Indian Constitution. Although Bhagwati $\mathrm{J}$, one of the judges had expressed his intention to include private authorities under state, he left the matter undecided on grounds of laxity of time in spite of the fact that the activity of producing chemicals and fertilisers is deemed by the state to be an industry of vital public interest, whose public import necessitates that the activity should be ultimately carried out by the state itself. The Mehta case remains important as the court observed that the American doctrine of state action might be applicable in India, and therefore, all the functions of a body judged as 'state' need not be public functions.

In Zee Telefilms Ltd. $v$ Union of India ${ }^{40}$ it was held that a board like the Board of Control for Cricket in India (BCCI) is not a state under article 12 and its functions do not amount to public functions. Every entity regulating the fundamental rights under article 19 (1) (g) is not necessarily a state within the meaning of article 12. In Rahul Mehra $v$ Union of India, ${ }^{41}$ it was observed that when the government stands by and lets a body like BCCI assume the prerogative of being a sole representative of India for cricket by permitting BCCI to choose the team for India for appearance in events like the World Cup, then it necessarily imbues BCCI with the public functions at least in so far as the selection of the team to represent India and India's representation in international cricket. Regarding the question: to what extent public law norms are applicable to private bodies? The nature of the function fulfilled by the company may be one aspect of consideration to reach the decision. 'Public functions test' helps the courts to find out instrumentalities of state under the expression 'all local or other authorities' to be treated as state. The public functions test lays down that when the functions performed by private bodies could be identified with state functions, they would become state actors in relation to the public functions performed by them.

\section{Regulation of Privatisation}

To be constitutionally valid, there must be regulation of the process of privatisation and privatised activities. In Delhi Science Forum $v$ Union of India ${ }^{42}$ the Indian apex court held that the central

\footnotetext{
40 (2005) 4 SCC 649.

$41 \quad 114$ (2004) DLT 323.

421996 SCC (2) 405.
} 
government and the telecom regulatory authority are not to behave like sleeping trustees, but have to function as active trustees for the public good to ensure that the private sector contributes more to the development of the telecom network in India and for introduction of plurality in the telecom sector.

Specific decisions for privatisation need to be transparent and accountable. The decision to set up Rs. 1300 crore high speed data network 'Sankya Vahini', which was designed to become a national data backbone for India has raised several questions as the hasty way the project was cleared with a foreign company even before asserting its assets, shareholding pattern and identity.

As Nambiar argues, one of the principal objectives in undertaking privatisation would be to ensure that the government does not crowd out the market and that privatisation increases competition in the provision of goods and services. The purpose of any regulatory agency is to ensure that competition is protected. Particular suppliers of goods and services should not receive any specific protection. The intention of any regulatory agency would be to ensure that competition is allowed to prevail in the market without distortion or intervention, either from an external source - such as the government - or from within - more powerful firms in the market. ${ }^{43} \mathrm{He}$ also states that while the practice of privatisation was, in essence and in principle, appropriate for Malaysia, execution was flawed due to a lack of the right institutions. ${ }^{44}$

The privatisation policy of the government needs to be straightforward so as to permit a clear-cut uniform business position. The privatisation policy has to be powerful to overcome overlapping interests, complex conflicts and controversy. For instance the recommendations by the Task Force Committee of the Confederation of Indian Industry (CII) to the Indian government to close three nationalised banks, namely, the Indian Bank, UCO Bank and the United Bank of India invited several criticisms in the country because of the adverse impact it would have on the depositors, clients, borrowers, employees and the general public. This report created panic and a kind of uncertainty among the general public, the borrowers from the banks and the depositors. More interestingly, the taskforce consisted of two corporate sector industrialists, who owed Rs. 500 crore and Rs. 350 crore respectively to these nationalised

$43 \quad$ Nambiar, "Revisiting Privatisation," 23. 
banks. They have not only recommended the closure of these banks but also liquidation of all three banks. It was criticised that fearing exposure, they had recommended liquidation of all the three nationalised banks.

\section{Impact}

Privatisation presents complex social and economic challenges. Privatisation decisions also have social and distributive implications apart from its potential effect on human rights. Examples from other countries show that privatisation in areas like operation of welfare-towork programs, prison management (establishment of privately owned and operated prisons) or privatising the training of public service professionals etc. has the potential to indirectly influence public service.

Though disinvestment is a part of fiscal policy, the re-divide between public-private is a combination of fiscal, industrial and tariff policy combined with strands of policy on public enterprise reform. ${ }^{45}$ India lacks a comprehensive policy on privatisation. A non-policy on privatisation as it prevails now in India has its impact on the economy. Lack of policy might favour the considerations of political expediency in the short run but at the cost of sacrificing sound economic management in the long run.

Many small privatised firms cannot effectively compete with the large firms in matters of technology, economies of scale, and resource-use efficiency. The large firms, through their strategy of concentration and centralisation of capital, are engulfing the small firms by means of takeovers, amalgamations and mergers. Thus, competition is gradually reduced in this process and large-scale conglomerative monopoly power gets accentuated, rendering social efficiency at causality. This presents a contradiction between the objective of privatisation and its actual manifestation. ${ }^{46}$

Reform oriented policies may express anti-labour and anti-poor tendencies. The Voluntary Retirement Scheme offered by the Indian Government has been sharply criticised. Many privatisation drives rendered lakhs of daily wagers unemployed. ${ }^{47}$ Farmers in several

\footnotetext{
45 G Gouri, "Privatisation and Public Sector Enterprises in India: Analysis of Impact of Non-policy," Economic and Political Weekly 48 (1996): 63.

46 Ghosh, "Privatisation," 12.

47 D Arora, "The Privatisation of Governance," Mainstream, March 10, 2001, 20.
} 
states committed suicide due to subsidy reductions. Many small and marginal farmers have decided to quit farming due to growing pressure from the corporate interests keenly moving into the largescale agricultural domain.

Further, the private sector gets sufficient opportunity in the era of open market to accumulate great economic power. Accumulation of economic powers generally leads to corruption and exploitation of weaker sections.

\section{Challenges}

Privatisation in most developed countries including Europe is different from developing countries in as much as it involves essentially a fundamental change in the concept of property relations in the larger society itself. There is wide gap between rhetoric and reality in terms of actual privatisation. ${ }^{48}$ There is inadequate appreciation and technical complexities involved in privatisation and neglect of social and labour matters. ${ }^{49}$

The failure of privatisation can be due to institutional or political failure. In many developing countries certain privatisation attempts failed due to weak political and economic institutions, problems of patronage, associated corruption and arbitrary state intervention. The major problems are poor choices, poor implementation and weak regulation, with a lack of credible commitment to contracts or policies. Privatisation does not necessarily improve incentives for efficiency or enhance the finance available for capital investment; successful privatisation depends on the state's institutional and political capacity to design and manage an appropriate set of subsidies. The failure of four major privatisations in Malaysia - the national sewerage company (IWK), Kuala Lumpur Light Rail Transit (LRT), national airline (MAS) and national car company (Proton) was due to political considerations that compromised institutional design and regulatory enforcement, leading to problems associated with

48 See, Bernardo Bortolotti and, Domenico Siniscalco, The Challenges of Privatisation: An International Analysis (London: Oxford University Press, 2004).

49 Venkata Ratnam, "Social and Labour Issues," 139. 
corruption. The success of privatisation depends on the effectiveness of state regulation and a state's institutional and political capacity. ${ }^{50}$

As privatisation creates private monopolies, there must be adequate regulation to prevent abuse of monopoly power. In privatisation, government loses out on potential dividends and private companies become more profitable and commanding. The public interest yields to the profit motive in privatisation drives have involved important public services such as health care, education etc. $^{51}$

\section{CONCLUSION}

In the era of globalisation, liberalisation and privatisation (GLP), privatisation has come to stay. However, better-run public enterprises have to be protected. For this, there should be public enterprise reform both at political and bureaucratic level to equip public sector enterprises to face international competitions. There is a growing realisation at all levels of the need to attend to the concern of equity without which the privatisation reforms are likely to generate opposition and resistance. The enterprises should be prepared to face domestic and external competitions. In many countries such reforms include exposing public enterprises to domestic and external competitions, by freeing public enterprises' managers from noncommercial goals and government interference from day-today decision making, and by developing institutional mechanisms and performance evaluation systems to hold managers accountable for results. However, such reforms have to be well designed and politically and technically sound to implement. Reform programmes must also include enhancement of managerial autonomy and accountability. While creating an enabling environment which is investment friendly, the state has to ensure inclusive growth by addressing the imbalances and people left out in the growth process. Fairness and good faith must be ensured in the activities of private bodies performing state functions subjecting it to the process of judicial review. Courts' supervisory jurisdiction helps to ensure that private bodies performing public functions do not abuse their power

\footnotetext{
50 Jeff Tan, Privatization in Malaysia Regulation, Rent-seeking and Policy Failure (New York: Routledge, Malaysian Studies Series, 2008).

51 For challenges, also see, Arben Malaj and Fatmir Mema, Strategic Privatisation, its Achievements and Challenges (Bamberg: BERG, 2003).
} 
and do not act arbitrarily, capriciously, unreasonably or unfairly. Litigation and the possibility of litigation can play a useful regulatory role. 